\title{
Effect of dodecanol additive on auto-ignition properties of diesel oil and ethanol blends
}

In order to increase the possibility of utilizing ethanol to propel the combustion ignition engines, ethanol or methanol blends with diesel oil or other similar fuels are used. However, ethanol has a low solubility index in diesel fuel especially at low temperatures, which requires the use of additives to improve this feature. The paper presents the results of comparative tests of the derived cetane number of diesel fuel blend with ethanol and the addition of dodecanol which is used to improve the miscibility of ethanol with diesel fuel. The results of tests indicate that the effect of dodecanol additive in blended diesel fuel-ethanol on the auto-ignition properties of such fuel is negligible.

Key words: diesel fuel, ethanol, derived cetane number, alternative fuels

\section{Introduction}

Introduction by the European Union of increasingly restrictive standards on toxicity of flue gases emitted by combustion engines necessitates the search for fuels that would be environmentally friendly and cost-competitive as compared with petroleum-based fuels. Alternative fuels having been tested in recent years are ethanol and methanol or their blends with diesel fuel. The following arguments support the use of alcohols as alternative fuels:

- they come from renewable sources,

- cheap and simple production process,

- possibility of reducing emission of solid particles.

The use of alcohols as a pure fuel for propulsion of compression ignition engines is not economical because it requires costly modifications of the propulsion system. In order to increase the ability of ethanol to propel this type of engines, ethanol or methanol blends with diesel fuel or other fuels are used [3]. As an engine fuel, ethanol is characterised by more favourable properties than methanol [10]. Unlike methanol, it is better blended with diesel fuel. Ethanol miscibility with diesel fuel is affected by the presence of water in fuel, even small quantity of which can cause a separation of blended components.

The use of a blended ethanol-diesel fuel as a fuel for the propulsion of compression ignition engines has some limitations, including among others lower viscosity compared to diesel fuel and relatively low stability and ability to blend with diesel fuel.

One of the additives that improves the stability of diesel fuel blend with ethanol and improves their miscibility is the dodecanol. It is characterized by good solubility in both of these fuels and its volume fraction in the blend may amount up to $3 \%$ [4]. However, it has a low pour point, which can lead to blend gelling [11].

One of the critical problems in the use of ethanol blends with diesel fuel is the very low susceptibility of ethanol to auto-ignition processes [8]. Fuel auto-ignition ability is determined by the cetane number (LC) or derived cetane number $(\mathrm{DCN})$. The greater the value of these parameters, the greater the fuel susceptibility for auto-ignition. The following methods are used to determine the cetane number [9]:

- method consisting in calculating the value of derived cetane number based on the average value of ignition delay measured during fuel combustion in a constant volume combustion chamber,

- spectral analysis in the medium infra-red,

- method consisting in comparing the blends tested with analogous blends of known cetane number with a use of a test engine under standard test conditions.

The paper presents the results of the determination of derived cetane number of diesel fuel with different volume fractions of ethanol and for the same blends with the addition of dodecanol, which made it possible to determine its effect on DCN. In order to determine DCN value, the normative test method consisting in fuel combustion in a constant volume combustion chamber was used [1].

\section{Test facility and test methodology}

Determination of derived cetane number of diesel fuel and diesel fuel blend with ethanol with addition of dodecanol was conducted according to ASTM D7668 standard. This standard specifies accurately the determination of derived cetane number during the combustion of fuel in a constant volume combustion chamber.

CID 510 (Fig.1) was manufactured by Walter Herzog company by PAC (USA). This device meets the requirements of this standard and was used to determine the derived cetane number. In this device, determination of DCN is based on direct injection of fuel into a constant volume combustion chamber in which synthetic air is being heated. According to the standard procedure, a single measurement step consists of five initial combustion cycles and fifteen test cycles. Based on the test cycles, the ignition delay value (ID) and the combustion delay value (CD) are calculated. Triggering of the signal that controls the electromagnetic valve of fuel injector is assumed as the beginning of the auto-ignition delay period, while the increase of pressure in the combustion chamber over $0.02 \mathrm{MPa}$ relative to the static pressure is assumed as the end of this period. The time between triggering of the signal that controls the electromagnetic valve of 
fuel injector and the moment of reaching the half of the pressure increase in the combustion channel relative to initial pressure in the chamber is assumed as the combustion delay period. In the method discussed the injection time corresponds to duration of the injector control signal [8].

Determination of DCN value was carried out for seven samples with different volume fraction of ethanol in diesel fuel. Dodecanol additive was constant and amounted to $2 \%$. Contaminated and dehydrated ethanol, the basic characteristics of which are shown in Table 1 was used for blends.

Table 1. Basic properties of ethyl alcohol [5]

\begin{tabular}{|l|c|c|}
\hline Parameter & Value & Unit \\
\hline Alcohol content at $20^{\circ} \mathrm{C}$ & 99.9 & $\%$ \\
\hline Density & 0.7897 & $\mathrm{~g} / \mathrm{cm}^{3}$ \\
\hline Esther content & $<0.2$ & $\mathrm{mg} / 100 \mathrm{~cm}^{3}$ \\
\hline Methanol content & $<0.6$ & $\mathrm{mg} / 100 \mathrm{~cm}^{3}$ \\
\hline $\begin{array}{l}\text { Denatonium benzoate } \\
\text { content }\end{array}$ & 1 & $\mathrm{~g} / 100 \mathrm{dm}^{3}$ \\
\hline Water content & $<=0.1$ & $\%(\mathrm{~m} / \mathrm{m})$ \\
\hline Auto-ignition temperature & 425 & ${ }^{\circ} \mathrm{C}$ \\
\hline
\end{tabular}

Diesel oil used for tests could contain in accordance with the norm up to 7\% FAME and up to $200 \mathrm{mg} / \mathrm{kg}$ water.

Selected dodecanol parameters are presented in Table 2. Determination of fuel samples is presented in Table 3.

Table 2. Basic properties of dodecanol [6]

\begin{tabular}{|c|c|c|}
\hline Parameter & Value & Unit \\
\hline Density at $16^{\circ} \mathrm{C}$ & 0.9 & $\mathrm{~g} / \mathrm{cm}^{3}$ \\
\hline Water solubility at $25^{\circ} \mathrm{C}$ & 0.037 & $\mathrm{~g} / 1$ \\
\hline Auto-ignition temperature & 275 & ${ }^{\circ} \mathrm{C}$ \\
\hline Ignition temperature at $101.3 \mathrm{kPa}$ pressure & 134.8 & ${ }^{\circ} \mathrm{C}$ \\
\hline Melting/freezing point at $101.3 \mathrm{kPa}$ pressure & 24 & ${ }^{\circ} \mathrm{C}$ \\
\hline
\end{tabular}

Table 3. Fuels used for auto-ignition tests

\begin{tabular}{|l|c|c|c|}
\hline \multirow{2}{*}{ Fuel determination } & \multicolumn{3}{|c|}{ Share \% v/v } \\
\cline { 2 - 4 } & Diesel oil & Ethanol & Dodecanol \\
\hline ON 100 & 100 & 0 & 0 \\
\hline ON+ET 5 & 95 & 5 & 0 \\
\hline ON+ET10 & 90 & 10 & 0 \\
\hline ON+ET15 & 85 & 15 & 0 \\
\hline ON+ET5+D & 93 & 5 & 2 \\
\hline ON+ET10+D & 88 & 10 & 2 \\
\hline ON+ET15+D & 83 & 15 & 2 \\
\hline
\end{tabular}

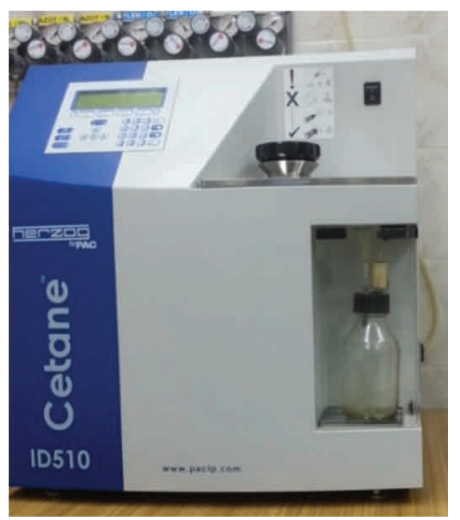

Fig. 1. Device for determination of derived cetane number CID 510
The prepared blends were stored in closed containers due to hygroscopicity of ethanol at room temperature of 20 $\pm 2{ }^{\circ} \mathrm{C}$. Under these conditions, for $5 \%$ and $10 \%$ ethanol blends, homogeneous and clear blends were obtained. Whereas for a sample of $15 \%$ ethanol, it was not possible to obtain a homogeneous blend (Fig. 2).

The remaining samples were prepared by adding $2 \%$ $(\mathrm{v} / \mathrm{v})$ of dodecanol, maintaining the assumed ethanol content $(5,10$ and $15 \%)$ and thereby reducing the content of diesel fuel in the sample.

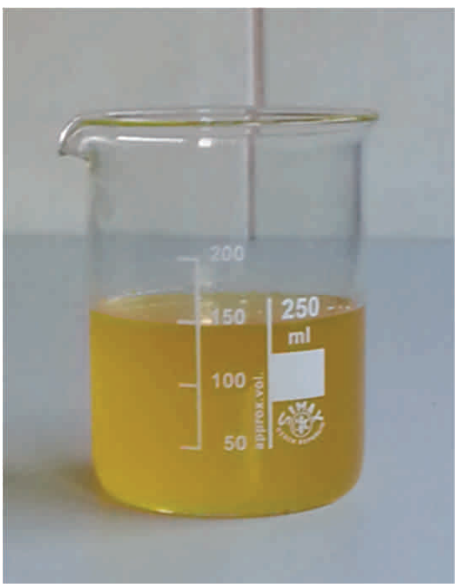

Fig. 2. Diesel fuel blend with $15 \%$ volumetric content of ethanol

The use of dodecanol improved miscibility of ethanol with diesel fuel. For all ethanol contents in diesel fuel a homogeneous and stable blend was obtained. Figure 3 shows a comparison of diesel fuel with $15 \%(\mathrm{v} / \mathrm{v})$ ethanol and $2 \%(\mathrm{v} / \mathrm{v})$ dodecanol additive (1) and without dodecanol (2) at $20^{\circ} \mathrm{C}$.

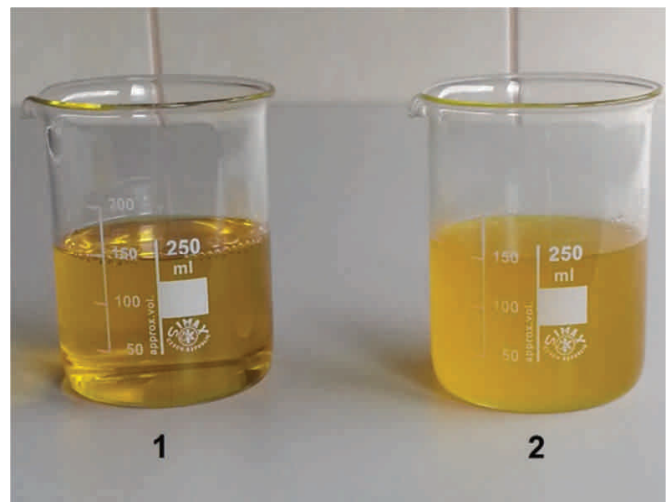

Fig. 3. Diesel fuel blend with $15 \%$ ethanol content: 1 - with dodecanol, 2 without dodecanol additive

As one can see, the use of dodecanol has led to obtaining a homogeneous blend that has also been stable under conditions that cause the increase of water content in the sample.

\section{Test results and their analysis}

The results of determination of DCN for the blends tested. The graph shows that no blend of diesel fuel with ethanol, regardless of the fact whether dodecanol was added or not, has failed to meet the requirements in terms of derived 
cetane number that cannot be less than 51 in accordance with PN-EN 590 standard. When adding the dodecanol, a slight increase in DCN may be observed, whereas the biggest increase (approx. 1.3\%) was observed for blends with the lowest ethanol content amounting to 5\%. Increasing the volume fraction of ethanol in diesel fuel resulted in a decrease in DCN. It has been also observed that with the increase in the volume fraction of ethanol, the effect of dodecanol additive on DCN decreases.

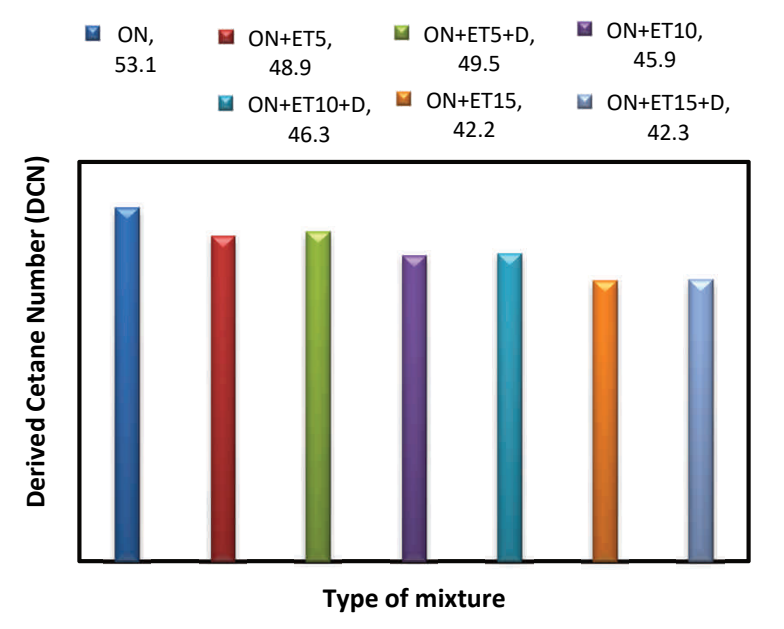

Fig. 4. DCN value for the blends tested

Figure 5 shows the results of auto-ignition delay (ID) for all the blends tested. As one can see, the use of dodecanol practically did not affect the value of this parameter.

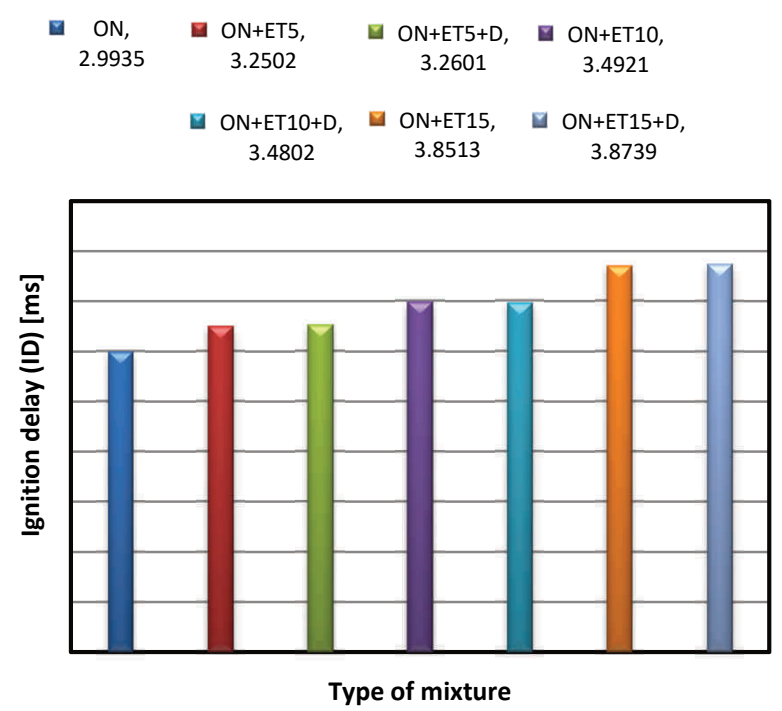

Fig. 5. Auto-ignition delay (ID) values for the blends tested

Figure 6 shows the results of combustion delay (CD) values. Along with the increase in ethanol volume fractions, the duration of this period increases and the use of dodecanol only results in a change of this parameter at the level not exceeding $1.5 \%$. The biggest differences occur here, similarly as in the case of DCN, for a $5 \%$ ethanol blend.

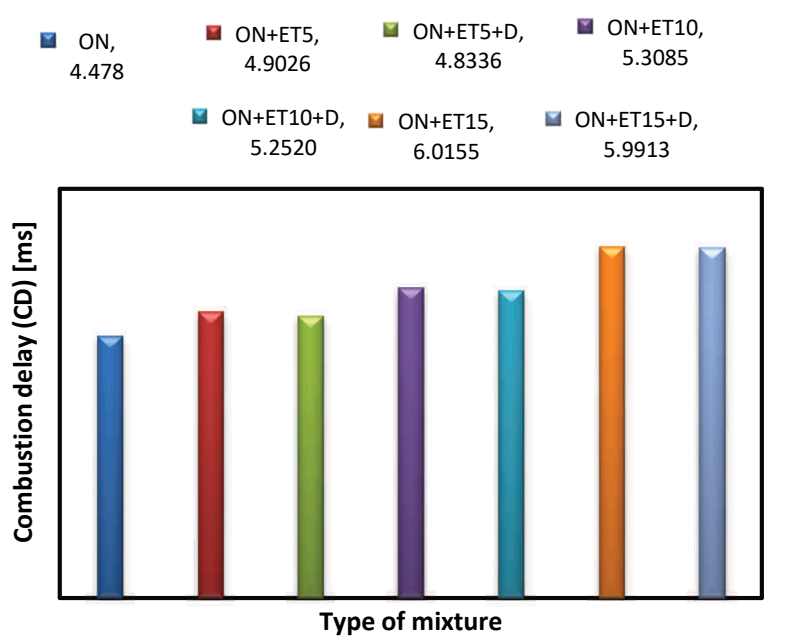

Fig. 6. Combustion delay (CD) values for blends tested

\section{Conclusions}

Addition of $2 \%(\mathrm{v} / \mathrm{v})$ of dodecanol to diesel fuel blends with ethanol practically does not affect the DCN value. As can be seen from the above, in the applied concentration, dodecanol is a neutral additive with respect to auto-ignition properties of fuels.

Along with the increase in ethanol content in the blend with diesel fuel, the DCN value is being decreased. None of the tested diesel fuel blends with ethanol met the regulatory requirements for derived cetane value, which should amount to 51 according to EN-PN 590 standard. According to American ASTM D975 standard, the minimum cetane number is 40 [2]. Therefore, a blend containing up to $15 \%$ of ethanol meets the requirements specified in the above standard. The World Fuel Charter specifies the requirements for five diesel fuel categories from 1-5, for which the minimum cetane number is $48,51,53,55$ and 55 , respectively [12]. The conducted tests of cetane number indicate that diesel fuel with $5 \%$ of ethanol meets the cetane number requirements for $1^{\text {st }}$ category of diesel fuel. In order to allow for marketing of this type of fuel it is necessary to use the additives that would increase the DCN value in such a way that these blends could meet the current requirements for fuels for combustion ignition engines or change of regulatory requirements to the American model is needed.

The addition of dodecanol to blends of diesel fuel and dehydrated ethanol improves the miscibility of these fuels. It may be noticed in particular for higher concentrations of ethanol (15\%) for which when preparing these blends some difficulties with miscibility and stability of this blend occurred. Already at a relatively high temperature (about $20^{\circ} \mathrm{C}$ ), separation of blend components occurred, which is also demonstrated by test results presented in the study [7].

Dodecanol improves the miscibility of diesel fuel and ethanol and, what is important, remains neutral with respect to auto-ignition properties of these blends. 


\section{Bibliography}

[1] ASTM D7668 - Standard test method for determination of derived cetane number (DCN) of diesel fuel oils - ignition delay and combustion delay using a constant volume combustion chamber method, 2014.

[2] ASTM D975 - standard specification for diesel fuel oils, 2014.

[3] CORKWELL, K.C., JACKSON, M.M. Lubricity and injector pump wear issues with e-diesel fuel blends. SAE Technical Paper. 2002, 2002-01-2849.

[4] DI, Y., CHEUNG, C.S., HUANG, Z. Experimental study on particulate emission of a diesel engine fuelled with blended ethanol-dodecanol-diesel. Aerosol Science. 2009, 40.

[5] Karta charakterystyki: Alkohol etylowy całkowicie skażony. Alpinus 2016.

[6] Karta charakterystyki: 1-Dodekanol $\geq 98 \%$ do syntezy. Carl Roth $\mathrm{GmbH}+$ Co KG. Karlsruhe 2016.

[7] KRZEMIŃSKI, A., KUSZEWSKI, H., USTRZYCKI, A. Wpływ dodatku etanolu na lepkość kinematyczną oleju na-

Artur Krzemiński, MEng. - Faculty of Mechanical Engineering and Aeronautics at Rzeszów University of Technology.

e-mail:ArtKrzem@prz.edu.pl

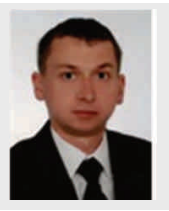

Prof. Kazimierz Lejda, DSc., DEng. - Faculty of Mechanical Engineering and Aeronautics at Rzeszów University of Technology.

e-mail:KLejda@prz.edu.pl pędowego. Monografia pod redakcja naukowa K. Lejdy. Seria: Transport. 2016, 7, Rzeszów.

[8] KUSZEWSKI, H., JAWORSKI, A., LEJDA, K. et al. Badania pochodnej liczby cetanowej mieszanin oleju napędowego z etanolem. Silniki Spalinowe. 2015, PTNSS-2015-3488.

[9] KUSZEWSKI, H., JAWORSKI, A., LEJDA, K. et al. Oznaczanie pochodnej liczby cetanowej wybranych paliw na podstawie spalania w komorze o stałej objętości w aspekcie ich zastosowania w silniku o zmiennym stopniu sprężania VCR. Mechanika Czasopismo Techniczne. 2012.

[10] LAPUERTA, M., GARCIA-CONTERAS, R., CAMPOSFRNAANDEZ, J., DORADO, M.P. Stability, lubricity, viscosity, and cold - flow properties of alcohol - diesel blends. Energy Fuels. 2010, 24.

[11] LIU, H., HU, B., JIN, C. Effects of different alcohols additives on solubility of hydrous ethanol/diesel fuel blends. Fuel. 2016, 184.

[12] Worldwide fuel charter. Fifth edition. September 2013.
Hubert Kuszewski, PhD - Faculty of Mechanical Engineering and Aeronautics at Rzeszów University of Technology.

e-mail: HKuszews@prz.edu.pl
Adam Ustrzycki, DEng. - Faculty of Mechanical Engineering and Aeronautics at Rzeszów University of Technology.

e-mail:AUstrzyc@prz.edu.pl 